\title{
ПРОГНОЗУВАННЯ ПЕРИНАТАЛЬНИХ УСКЛАДНЕНЬ У ЖІНОК ІЗ НЕВИНОШУВАННЯМ ВАГІТНОСТІ У РАННІ ТЕРМІНИ ГЕСТАЦІЇ (ОГЛЯД ЛІТЕРАТУРИ)
}

\section{В.М. Соловей}

Буковинський державний медичний університет, м. Чернівці, Україна

\section{Ключові слова:} прогнозування, невиношування, вагітність, ранні терміни гестації, перинатальний ризик

Клінічна та експериментальна патологія 2021. T.20, №3 (77). С. 96 - 105.

DOI:10.24061/1727-4338. XX.3.77.2021.14

E-mail: solovei.valentyna@bsmu. edu.ua
Мета роботи - проаналізувати сучасні погляди на механізми розвитку перинатальних ускладнень у жінок із невиношуванням вагітності в першому триместрі гестації з метою їх прогнозування.

Висновки. Показана необхідність подальшого вивчення иієї проблеми, $з$ урахуванням етіопатогенезу, з метою розроблення алгоритмів прогнозування гестаційних ускладнень та вчасної діагностики, щчо дасть змогу покращити перинатальні наслідки. Тому пріоритетним завданням, спрямованим на зниження репродуктивних втрат, є профілактика невиношування вагітності шляхом пошуку нових скринінгових маркерів, які виявлятимуть доклінічні форми патології.

\section{Ключевые слова:} прогнозирование, невынашивание, беременность, ранние сроки гестации, перинатальный риск.

Клиническая и экспериментальная патология C. $96-105$. 2021. T.20, №3 (77).

\section{ПРОГНОЗИРОВАНИЕ ПЕРИНАТАЛЬНЫХ ОСЛОЖНЕНИЙ У ЖЕНЩИН С НЕВЫНАШИВАНИЕМ БЕРЕМЕННОСТИ В РАННИЕ СРОКИ ГЕСТАЦИИ (ОБЗОР ЛИТЕРАТУРЫ)}

\section{В.М. Соловей}

Цель работы - проанализировать современные взгляды на механизмь развития перинатальных осложнений с иелью прогнозирования их у женщин с невынашиванием беременности в первом триместре гестации.

Выводы. Показана необходимость дальнейтего изучения данной проблемь с учетом этиопатогенеза, с иелью разработки алгоритмов прогнозирования гестационных осложнений и своевременной диагностики, что позволит улучшить перинатальные исходы. Поэтому приоритетной задачей, направленной на снижение репродуктивных потерь, является профилактика невынашивания беременности путем поиска новых скрининговых маркеров, выявляюших доклинические формы патологии.

\section{Key words:} prognosis, miscarriage, pregnancy, early gestation, perinatal risk.

Clinical and experimental pathology 2021. Vol.20, № 3 (77). P. 96 - 105.

\section{PREDICTION OF PERINATAL COMPLICATIONS IN WOMEN WITH NONCARRYING OF PREGNANCY AT EARLY GESTATION TERMS (LITERATURE REVIEW)}

\section{M. Solovei}

Objective - to analyze modern views on the mechanisms of perinatal complications' development in order to predict them in women with miscarriage in the first trimester of gestation.

Conclusions. The need for further study of this problem, taking into account the ethiopathogenesis, in order to develop algorithms for predicting gestational complications and timely diagnosis, which will improve perinatal outcomes, was shown. Therefore, the priority task, aimed at reducing reproductive losses, is the prevention of miscarriage by finding new screening markers that will detect preclinical forms of pathology.

\section{Вступ}

Невиношування вагітності є однією найактуальніших проблем у сучасному акушерстві. На сьогодні питання прогнозування, запобігання та профілактики перинатальних ускладнень потребують чіткого розуміння механізму розвитку та їх вплив на плід.

Своєчасна діагностика i розробка алгоритмів 
прогнозування гестаційних ускладнень 3 урахуванням етіопатогенезу дасть змогу покращити перинатальні наслідки. Відомо, що жінки зі звичним невиношуванням в анамнезі характеризуються ускладненим перебігом наступної вагітності (передчасні пологи, гестаційний діабет, затримка росту плода, передчасне відшарування нормально розташованої плаценти, гестаційна артеріальна гіпертензія, прееклампсія, низька оцінка новонародженого за шкалою Апгар) [1].

Серед основних причин ранніх втрат вагітності виділяють генетичні фактори [2], аномалії розвитку матки, гіперпластичні процеси, внутрішньоматкові синехії, міому матки [3], інфекційно-запальні захворювання, зумовлені умовнопатогенними мікроорганізмами, що виявляються у 20\% пацієнток і вірусно-бактеріальними асоціаціями - у 70\%. При наявних хронічних запальних процесах у жінок, за даними ряду авторів, виявляються: стафілокок (15\%); стафілокок в асоціації з кишковою паличкою $(11,7 \%)$; ентерококи $(7,2 \%)$; вірус простого герпесу (ВПГ) (20,5\%); хламідії (15\%); мікоплазми $(6,1 \%)$; уреаплазми $(6,6 \%)$; гарднерели $(12,5 \%)$ [4]. Ендокринна патологія становить від 30\% до $78,2 \%$, що, залежно від походження, реалізується структурно-функціональною недостатністю жовтого тіла яєчника.

Нині в якості можливих етіологічних факторів переривання вагітності розглядаються гіпергомоцистеїнемія, гіперпролактинемія, інсулінорезистентність, ожиріння, незадовільні показники спермограми, недостатність прогестерону, патологія щитовидної залози, імунні порушення. Незважаючи на значний інтерес дослідників до вивчення причин цієї патології, у 50\% випадків етіологія залишається невстановленою, і в $і 1 і$ основі лежать порушення імунітету $[1,5]$.

\section{Мета роботи}

Проаналізувати сучасні погляди на механізми розвитку перинатальних ускладнень у жінок із невиношуванням вагітності в першому триместрі гестації з метою їх прогнозування.

\section{Основна частина}

Одним із прогностичних критеріїв невиношування вагітності $€$ стрес, який знижує продукцію прогестерону і призводить до порушення імунної толерантності материнського організму, будучи причиною відторгнення плода. При цьому стрес $\epsilon$ етіологічним фактором рецидивуючих втрат вагітності протягом 3 тижнів після зачаття: збільшується ймовірність викидня у 2,7 раза, що пов'язано $з$ підвищенням рівня кортизолу в матері вище від нормальних значень. При впливі стресового чинника активується перекисне окислення ліпідів. Вважається, що в цьому випадку медіатором служить нейропептид субстанція $\mathrm{P}$ (SP), що виділяється нервовими закінченнями і призводить до збільшення вироблення фактора некрозу пухлини $\alpha$ (TNF- $\alpha$ ) імунокомпетентними клітинами матковоплацентарного комплексу. Подібно до стресу, SP Клінічна та експериментальна патологія. 2021. Т.20, № 3 (77) підвищувала частоту репродуктивних втрат за рахунок стимуляції вироблення TNF- $\alpha$ лімфоцитами. Оскільки макрофаги вносять значний вклад у синтез плацентарного TNF- $\alpha$, a SP здатний модулювати ïx функції, можна припустити, що абортогенний ефект цих клітин обумовлений індукцією запальної відповіді [1].

Доведено, що в розвитку ускладнень вагітності важливу роль відіграє порушення процесів апоптозу фетоплацентарного комплексу [6].

На сьогодні увагу вчених привертають імунні механізми самовільного переривання вагітності, які в половині випадків проявляються патологічними змінами на різних рівнях імунної системи i неадекватною реакцією материнського організму на антигени батька.

На ранніх термінах гестації серед імунних факторів, що призводять до втрати вагітності, виділяють аллоімунні, коли імунна відповідь спрямована проти плода. До них зараховують порушення у системі головного комплексу гістосумісності та в клітинно-імунному механізмі, зокрема у тій його частині, що стосується Т-хелперів. Інші фактори - аутоімунні, коли імунна материнська відповідьспрямованапротивласнихклітинітканин.До цієї групи факторів зараховують: антифосфоліпідний синдром (АФС), антитіла (АТ) до $\beta$-хоріонічного гонадотропіну людини (ХГЧ), АТ до прогестерону, тиреоїдних гормонів. Антифосфоліпідні АT, вовчаковий антикоагулянт (BA), антиспермальні AT, антитиреоїдні АТ та інші імунологічні фактори сприяють репродуктивній дисфункції. Про існування двох класів лімфоцитів, які продукують різні цитокіни: Т-хелпери 1-го (Th1) і Т-хелпери 2-го (Th2) типів, відомо з середини 80-х років XIX століття. Th1 продукують інтерферон гама (IFN- $\gamma$ ), інтерлейкін-2 (IL-2), TNF- $\alpha$, тоді як Th2 виробляють IL-4, IL-5, IL-10, IL-13, які $є$ протизапальними цитокінами. Диференціація клітин Th1 з попередника Т-хелперів (Th0) індукується IL-12, синтезується макрофагами i дендритними клітинами як реакція на антигенну стимуляцію. Клітини Th2 диференціюються під дією IL-4, який продукується базофілами і огрядними клітинами. Тh1-клітини відіграють важливу роль у формуванні реакцій клітинного імунітету, які спрямовані проти вірусних і внутрішньоклітинних патогенів та беруть участь у реакціях гіперчутливості сповільненого типу (ГСТ). Th2-клітини відповідають за реакції гуморального імунітету, підтримують проліферацію i диференціювання В-клітин, елімінацію позаклітинних патогенів та беруть участь у формуванні алергічних реакцій негайного типу.

У минулому столітті стало відомо, що вагітність являє собою «Тh2-феномен»: кількість материнських Th1-клітин, що відповідають за цитотоксичні реакції, знижена при вагітності, що запобігає відторгненню плода, а кількість клітин Th2-клітин збільшується. Незважаючи на існування цієї гіпотези в сучасній літературі, згідно 3 якою Th2-девіація $є$ основним механізмом захисту плода від материнських негативних реакцій. Місцеве оточення материнського фетального комплексу, представлене цитокінами Th2-

ISSN 1727-4338 https://www.bsmu.edu.ua 
типу, необхідне як для регуляції інвазивного росту, так і для диференціювання трофобласта і формування альтернативно активованих макрофагів (М2). М2, у свою чергу, є основними джерелами чинників зростання цитокінів, підтримують необхідний баланс Th1- i Th2-клітин у плацентарного ложі, а також сприяють виробленню Th2-типу цитокінів Т-лімфоцитами. Відомо, що макрофаги не тільки реалізують свої функції як фагоцити, але і беруть активну участь в імплантації, інвазії, плацентації та ангіогенезі $[1,7]$.

Вперше були відкриті макрофаги I.I. Мечниковим як клітини, основною функцією яких був фагоцитоз. При вагітності на ділянці імплантації вони являють собою головний клітинний компонент. Фіброзна i децидуальна тканини, які мають безпосередній контакт із плацентою, а також мезенхімальною стромою, багаті на макрофаги.

При фізіологічному перебігу вагітності децидуальна оболонка населяється лейкоцитами, при цьому макрофаги становлять до 30\% на ділянці імплантації і зберігаються протягом усієї вагітності. Як представники вродженої імунної системи, вони відіграють важливу роль у захисті материнського організму від інфекцій. Відомо, що імплантація бластоцисти в ендометрій можлива за рахунок підвищеної продукції прозапальних цитокінів, а супресія цієї запальної відповіді призводить до дефектів імплантації. Макрофаги і моноцити відіграють істотну роль у захисті материнського організму від патогенів, беруть участь у різних типах запальних процесів, а також $\epsilon$ антигенпрезентуючими клітинами. Дослідження показали, що трофобластні клітини на ранніх термінах гестації інгібують продукцію прозапальних цитокінів, таких як TNF- $\alpha$, моноцитами крові [8].

Для пояснення причин ранніх репродуктивних втрат на клітинно-тканинному рівні на сьогодні запропоновані такі механізми: надлишкова активність імунокомпетентних клітин, що негативно впливає на інвазивний трофобласт; шкідлива дію цитокінів на клітини трофобласту; а також судинні ефекти ряду цитокінів, що призводять до порушення матковоплацентарного кровоточу [1].

С твердження, що у жінок із репродуктивними втратами в анамнезі виявляється переважання прозапальних цитокінів, що призводить до оксидативного стресу, ендотеліальної дисфункції, змін у системі згортання крові, сприяючи неповноцінній інвазії і плацентації. Встановлено збільшення рівня сироваткового TNF- $\alpha 3$ ранніх строків вагітності у жінок зі звичним невиношуванням в анамнезі порівняно 3 жінками 3 первинним викиднем в анамнезі. В інших дослідженнях виявлено, що поліморфізм TNF- $\alpha$ не має зв'язку 3 ризиком репродуктивних втрат [1].

В останні роки доведено, що в розвитку ускладнень вагітності істотну роль відіграє порушення процесів апоптозу фетоплацентарного комплексу. Водночас фізіологічні фактори-індуктори й інгібітори апоптозу в організмі засвідчують про те, що програмована загибель клітини залежить від співвідношення проISSN 1727-4338 https://www.bsmu.edu.ua та антиапоптичних факторів i від регуляторних внутрішньоклітинних механізмів [1].

Під час імплантації, інвазії і плацентації макрофаги фагоцитують апоптичні клітини, тим самим, запобігаючи звільненню проімуногенного i прозапального внутрішньоклітинного вмісту; утворюються в результаті інвазії трофобласту і трансформації спіральних артерій. Трофобластні клітини $є$ резервуаром білків, які мають ознаки антигенної чужорідності для імунної системи матері, при звільненні яких внаслідок загибелі клітин відбувається посилення імунної відповіді, спрямованої проти ембріона $[1,8]$.

Окрім того, надмірний рівень апоптичних клітин часто призводить до неможливості повного очищення макрофагами матково-плацентарного комплексу від клітинного детриту, тому апоптичні клітини піддаються вторинному некрозу, пригнічуючи диференціювання трофобластних клітин. А отже, надлишковий апоптоз трофобласта здатний ініціювати системну запальну відповідь, посилюючи процеси імплантації, інвазії і плацентації. Відомо, що при фізіологічній вагітності фагоцитоз апоптозних клітин знижує вироблення прозапальних цитокінів (IL-1 $\beta$, IL-8 IL-12, TNF- $\alpha$ i IFN- $\gamma$ ) і збільшує секрецію імуносупресивних цитокінів (IL-10, IL-6, IL-1Ra). Можливість макрофагів впливати на загибель клітин регулюється ступенем поглинання апоптозних клітин [10]. Наприклад, макрофаги, стимульовані IFN- $\gamma$, ліпополісахаридами (ЛПС) або TNF- $\alpha$, викликають апоптоз клітин і при їх поглинанні процес індукції апоптозу пригнічується.

При імплантації ембріона стромальні клітини ендометрія зазвичай піддаються апоптозу 3 формуванням протизапального мікрооточення, підвищуючи вироблення цитокінів Th2-типу i пригнічуючи прозапальні процеси протягом усієї вагітності. Це можливо перемиканням макрофагів на синтез таких цитокінів як IL-10, IL-4, IL-6 при фагоцитуванні клітин плаценти або стінки матки, що вступили в апоптоз. Отже, видалення апоптозних клітин на ділянці імплантації, здійснене моноцитами i макрофагами, сприяє благополучному існуванню плаценти впродовж усього гестаційного періоду, що пояснює «безконфліктну» взаємодію макрофагів і клітин трофобласту в зоні імплантації.

На додаток до вищесказаного, макрофаги захищають трофобласт від інфекційних агентів. Складність полягає в тому, що ця відповідь потребує ретельного регулювання, щоб запобігти пошкодженню плаценти, що відбувається у випадку інфікування. Здатність макрофагів продукувати прозапальні цитокіни у відповідь на бактеріальні продукти - ЛПС - контролюється клітинами трофобласту на ранніх термінах гестації. Низькі концентрації ЛПС не здійснюють негативного впливу на вагітність. Трофобласт сам може обмежувати запальну відповідь макрофагів, змінюючи профіль продукованих ними цитокінів. В експериментальних роботах показано, що високі концентрації ЛПС призводять до викидня через вивільнення токсичних ембріональних речовин і TNF- $\alpha$ макрофагами для

Клінічна та експериментальна патологія. 2021. Т.20, № 3 (77) 
захисту материнського організму від тяжкої інфекції на шкоду розвитку вагітності $[1,8,11]$.

Процеси апоптозу можуть бути структурно розподілені на три незалежні етапи: ініціація (каскад протеїнокіназ), ефекторна фаза (активація каспаз i нуклеаз) i деградація. При цьому індукторами апоптозу $\epsilon$ i зовнішні (позаклітинні) сигнали, i внутрішні (внутрішньоклітинні) фактори. Сигнали сприймаються рецептором і послідовно передаються молекулам посередникам різного порядку, досягаючи ядра, де відбувається включення програми клітинної загибелі за рахунок активації «летальних» генів і супресії генів, які блокують реалізацію цієї програми.

Найбільш детально вивчена послідовність подій, що призводять до апоптозу в результаті взаємодії білків сімейства TNF зі специфічними рецепторами. Вивчено два шляхи реалізації ефекторної фази: зовнішній - рецептор-залежний сигнальний шлях, пов'язаний з участю рецепторів клітинної загибелі та внутрішній - мітохондріальний шлях.

Розвиток ефекторної фази по зовнішньому шляху відбувається за рахунок зв'язування рецептора зі специфічним лігандом 3 подальшою агрегацією рецептора i мультимолекулярного комплексу протеїнів.

Мітохондріальний або внутрішній шлях характеризується взаємодією між каспазами, проапоптотичними факторами 3 сімейства bcl-2 (Bax i Bad), цитохромом C, apoptosis inducing factor (AIF), які вивільняються мітохондріями. Достатня кількість білків bcl-2 експресується на зовнішній мітохондріальній мембрані, яка постійно виконує функцію захисту клітин від апоптозу за рахунок підтримки в інактивованому стані проапоптотичного білкового комплексу, у складі якого знаходиться прокаспаза-9, адаптер apoptotic protease activating factor-1 (Apaf-1), AIF, цитохром C та інші фактори. У сімействі білків bcl-2 також є група апоптозопосередкованих факторів. Для переходу клітини в режим апоптозу необхідне зв'язування bcl-2, що нейтралізуює його інгібуючу дію. Така взаємодія може здійснюватися будь-яким проапоптотичним фактором 3 групи bcl-2. У підсумку підвищується проникність мітохондріальної мембрани, вивільняється в цитоплазму цитохром С, зв'язування якого 3 Apaf-1 призводить до активації каспази-9, яка в подальшому активує каспазу-3. При реалізації ефекторної фази мітохондріального шляху апоптозу зазвичай спостерігається збільшення концентрації $\mathrm{Ca} 2+$ в цитоплазмі, що призводить до активації клітинних протеаз і ендонуклеаз, що беруть участь в фазі деградації $[8,9]$.

Основна роль індукторів апоптозу відводиться лігандам 3 сімейства TNF (TNF- $\alpha$, CD178, Trail, Tweak, LT $\alpha$, LT $\beta$, 4-1BBL, LIGHT), які експресуються трофобластом, стромою, моноцитами, макрофагами, Т-лімфоцитами [10]. Найбільш повно вивчений апоптоз в результаті взаємодії білків системи CD95CD178, для якої невідомі інші функції, окрім індукції апоптозу клітини. Fas (CD95, APO-1) - мембранний білок, який має у своїй структурі цитоплазматичний, трансмембранний i позаклітинний домени. У цитоплазматичному домені є гомологічний домен, необхідний для реалізації передачі сигналу смерті. При цьому внутрішньоклітинна частина рецептора пов'язана 3 клітинними ферментами, що викликають біохімічні зміни в молекулах білкових регуляторів. Fas також експресується на поверхні різних клітин: на тимоцитах, активованих Т- i В лімфоцитах, фібробластах, гепатоцитах, кератиноцитах, мієлоїдних клітинах. Цей рецептор активується відповідним антигеном - Fas-лігандом (FasL, APO$1 \mathrm{~L}, \mathrm{CD} 178)$, який є індуктором апоптозу. Мимовільні аборти супроводжуються підвищенням експресії Fas-L в децидуальних лімфоцитах i Fas у поза ворсинчастому трофобласті $[8,9,11]$.

FasL експресується на натуральних кілерах i активованих Т- лімфоцитах. Незважаючи на значне число експериментальних робіт, в літературі відсутні дані про процеси регуляції апоптозу на системному рівні у жінок із загрозою переривання вагітності на ранніх термінах і репродуктивними втратами в анамнезі.

В імунній системі CD95 і CD178 залучені в регуляцію імунних механізмів і цитотоксичність, опосередковану Т-лімфоцитами. CD95 в основному експресується зрілими Т-лімфоцитами, зростаючи після активації CD178 та роблячи Т-клітини більш чутливими до апоптозу. Тому секреція CD178 трофобластом $є$ одним із механізмів, за допомогою якого трофобласт здатний захистити себе від материнського імунного розпізнавання. При цьому апоптоз, опосередкований CD95-CD178системою, може бути пов'язаний із материнською імунотолерантністю до плода. Клітини, які вступили в апоптоз, виявляються і в материнській, і в плодовій зоні плаценти протягом фізіологічної вагітності.

Наявність цих клітин асоційоване 3 різними стадіями розвитку плаценти, таких як інвазія трофобласту, трансформація спіральних артерій, диференціювання трофобласту. На ранніх термінах гестації апоптоз стромальних клітин ендометрія звільняє місце для зростаючого плодового яйця, вони експресують CD95. У невеликій кількості на поверхні трофобласту також експресується CD95, але цей шлях активації апоптозу в ньому заблокований, однак у присутності IFN- $\gamma$ i TNF- $\alpha$ чутливість трофобласту підвищується до індукції апоптозу через систему CD95 - CD178. Встановлено, що мимовільні викидні супроводжуються збільшенням експресії CD95 у позаворсинчастому трофобласті.

Прозапальні цитокіни, такі як TNF- $\alpha$, здатні збільшувати експресію CD95 на поверхні клітин трофобласту та ендотеліальних клітин. Експресують на своїй поверхні CD178 активовані макрофаги, здатні ініціювати апоптоз цих клітин, приводячи до дострокового переривання вагітності. Взаємодія CD95-CD178 призводить до апоптозу гладком'язових клітин під час інвазії позаворсинчастого трофобласту в м'язовий шар спіральних артерій, приводячи до їх гестаційної трансформації. Фібриноїдні зміни стінки цих артерій призводять до їх розширення, забезпечуючи необхідний кровотік у плаценті, незалежно від впливу судинозвужувальних факторів.

ISSN 1727-4338 https://www.bsmu.edu.ua 
При відносній кількості $\mathrm{CD} 178+$ моноцитів $\leq 37,7 \%$ прогнозується розвиток загрозливого пізнього викидня; при відносній кількості CD 178+ моноцитів > 37,7\% прогнозується відсутність розвитку загрозливого пізнього викидня. Іншим шляхом індукції апоптозу $\epsilon$ взаємодія LIGHT 3 його специфічними рецепторами. LIGHT член суперсімейства TNF i $\epsilon$ трансмембранним протеїном II типу, що продукується дендритними клітинами, моноцитами, гранулоцитами, активованими Т-клітинами. У якості специфічних функціональних рецепторів LIGHT відомі herpes virus entry mediator (HVEM) i lymphotoxin $\beta$ receptor (LT $\beta R$ ) експресуються на активованих Т-клітинах, моноцитах, гранулоцитах, дендритних клітинах. Взаємодія LIGHT з LT $\beta$ R призводить до апоптозу LT $\beta R+$ клітин, а зв'язування LIGHT 3 HVEMпозитивними клітинами призводить до активації $\mathrm{i}$ проліферації Т-лімфоцитів, що відіграє ключову роль у захисті клітин від інфекційних агентів $[8,11,12]$

Доведено, що LIGHT i його рецептори експресуються на клітинах трофобласта та ендотеліальних клітинах [1]. Decoy receptor 3 (DcR3) є іншим рецептором LIGHT. Відомо, що DcR3 належить до класу «рецепторів-пасток», отже, при зв'язуванні його 3 LIGHT, DcR3 нейтралізує його біологічний ефект, призводячи до пригнічення проведення апоптоз-індукуючого сигналу, опосередкованого LIGHT. DcR3 також, будучи членом суперсімейства TNF- $\alpha$, не має трансмембранного домену.

Лігандами до DcR3, крім LIGHT, є CD178, а також інгібітор росту судинного ендотелію (VEGI). DcR3, перебуваючи в розчинній формі, послаблює взаємодію лігандів зі специфічними рецепторами, пригнічуючи ïx біологічну активність. Тому розчинний DcR3 може індукувати запуск апоптозу по Fas-шляху. Також DcR3 здатний блокувати прозапальний ефект, викликаний FasL i VEGI.

Механізми регуляції апоптозу через систему LIGHT i DcR3 при вагітності до цього часу вивчені недостатньо. В одиничних роботах встановлено, що DcR3 експресуються на клітинах цито- i синцитіотрофобласту, ендотеліальних клітинах. C припущення, що DcR3, можливо, бере участь y захисті трофобластних клітин від апоптозу, індукованого LIGHT.

Особливості системної та місцевої продукції LIGHT виявлені при вагітності, ускладненій прееклампсією. Встановлено, що розвиток прееклампсії пов'язаний зі збільшенням рівня LIGHT у периферичній крові та тканині плаценти. Клітини трофобласту беруть участь в інвазивному процесі та демонструють часткову функціональну схожість із пухлинними клітинами. Якщо 3 певних причин процес апоптозу клітин інвазії трофобласту не обмежується, то залежно від ступеня зростання рівня LIGHT розвиваються ускладнення вагітності. Ранній спонтанний викидень, прееклампсія, синдром затримки росту плода мають аналогічні патогенетичні механізми, що асоціюються з недостатньою інвазією трофобласту [14]. Проте згідно досліджень Н.В. Батрак зі співавторами, загроза переривання не ISSN 1727-4338 https://www.bsmu.edu.ua супроводжувалася змінами сироваткового рівня LIGHT. Системна продукція LIGHT не залежить від характеру перебігу вагітності у пацієнток зі звичним невиношуванням вагітності (ЗНВ) в анамнезі, а також від особливостей їх інфекційного статусу $[1,14]$.

У патогенезі акушерських ускладнень, а саме ЗНВ, важливу роль відіграють тромбофілії. Генетична природа ЗНВ включає кілька груп генів, відповідальних за невиношування вагітності. Поліморфізм генів факторів згортання $(1691 \mathrm{G} \rightarrow \mathrm{A}$ фактора V Leiden, $20210 \mathrm{G} \rightarrow$ А протромбіну, $455 \mathrm{G} \rightarrow \mathrm{A}$ фібриногену $\beta$, інгібітору активатора плазміногену 1-го типу (PAI-1) супроводжується як розвитком венозних тромбоемболічних ускладнень, так i може призводити до виникнення суто акушерських ускладнень. Розвиток останніх пов'язаний iз посиленням фізіологічної гіперкоагуляції під час вагітності, активацією процесів внутрішньосудинного тромбогенезу, порушенням глибини i якості імплантації, розвитку плаценти.

Відомо, що в жінок, що мали викидні до 12 тижнів вагітності, частіше ніж в інших трапляються такі акушерські ускладнення, як прееклампсія тяжкого ступеня, синдром затримки росту плода, внутрішньоутробна загибель плода, передчасне відшарування нормально розташованої плаценти. За даними низки авторів, питома вага основних спадкових тромбофілій у структурі ЗНВ становить 40-70 \% і є несприятливим фактором репродуктивних втрат, тромботичних ускладнень, низької якості життя.

Докази мультифакторіальної природи ЗНВ обгрунтовують необхідність розширити спектр аналізованих ДНК-поліморфізмів при встановленні причин невиношування за рахунок маркерів ендотеліальної дисфункції, артеріальної гіпертензії, патології фолатного циклу. Показано, що деякі тромбофілії, а особливо їхні поєднання,створюють значно вищий ризик для результатів вагітності. Пацієнткам, що мають генетично обумовлені фактори тромботичного ризику, показано динамічне дослідження стану системи гемостазу з визначенням рівня маркерів тромбінемії (Д-димер) $[15,16]$.

Інгібітор активатора плазміногену людини-1 (PAI-1) тісно пов'язаний з ембріональним розвитком та успішністю вагітності. У дослідженні Van Dijk (2020) [17] встановлено, що для варіантів мутації PAI-1 4G/5G та PAI-1 4G/4G існувала статистично значуща різниця між групами пацієнтів iз невиношуванням. У пацієнтів із 3 або більше абортами співвідношення було вищим, ніж у пацієнтів із 2 абортами із ЗНВ. Результати Лоскутової T.O. (2021), збігаються з дослідженням Zhao X (2020) [18], у яких встановлено зв'язок між поліморфізмом метилентетрагідрофолатредуктази (MTHFR) та ЗНВ, наголошено на необхідності проводити визначення цього поліморфізму у жінок групи ризику для профілактики повторних втрат вагітності.

Важливим $є$ не лише патологічні поліморфізми окремих генів, але і їх сумісний вплив, внаслідок якого має місце потенціювання їхньої дії. За обставин поєднаного впливу патологічних поліморфізмів

Клінічна та експериментальна патологія. 2021. Т.20, № 3 (77) 
ризик невиношування вагітності збільшується, що і представлено в прогностичній моделі Лоскутової Т.О, яка має чутливість 68,81 \% (95\% ДІ: 59,22 - 77,34 \%), а специфічність - 86,4\% (95\% ДІ: 76,32 - 98,14 \%) $[17,18,19]$.

Утробин М.В. у своїй роботі описує, що в оцінці ризику розвитку звичного викидня найбільше значення має розрахунок прогностичної цінності комбінації мутації гена MTHFR із підвищенням рівнів антитіл до Fc-фрагмента імуноглобуліну (прогностична цінність позитивного результату становила $50 \%$; прогностична цінність негативного результату - 74,4\%), мутації гена FII з підвищенням рівня антитіл до Fc-фрагмента імуноглобуліну (відповідно 100\% і 73,7\%), мутації гена FII 3 підвищенням рівнівня антитіл до тироглобуліну (відповідно 33,3\% і 73,5\%). У цьому дослідженні вперше виявлено комбінації мутацій генів PAI-1, FV, FII, MTHFR та підвищення рівня антитіл до Fcфрагмента імуноглобуліну і / або тироглобуліну, що визначають підвищений ризик розвитку звичного викидня [20].

Прогностичні критерії переривання вагітності ранніх термінів з урахуванням вмісту триптофану i серотоніну в плазмі крові у жінок до появи клінічних симптомів загрози переривання були розроблені Ю.В. Кухарчик [21]. Згідно з результатами проведеного дослідження встановлено, що концентрація серотоніну нижче за 1,381 нмоль/л і триптофана нижче за 0,050 нмоль/л співвідноситься 3 клінічними проявами загрожуючого або самовільного викидня, а також наявністю переривання вагітності за типом вагітності, що не розвивається, аборту в ходу, неповного викидня [21].

Відомими маркерами прогнозування гестаційних ускладнень $є$ активні форми кисню, що зумовлюють розвиток оксидативного стресу - порушення балансу між продукцією вільних радикалів і факторів антиоксидантного захисту, та можуть самостійно чи разом $з$ іншими факторами впливати на розвиток i функціональний стан фетоплацентарної системи [22].

Найбільш інформативними показниками для ранньої діагностики та прогнозування перинатальних ускладнень у жінок $є$ параметри маткового кровотоку, рівень естрадіолу та тромбоцитів, рівні специфічних білків вагітності (вільного естріолу, $\beta$-хоріонічного гонадотропіну та РАРР-А) у сироватці крові, ехографічні показники: локальний гіпертонус, відшарування хоріону та його об'єм, клінічні прояви загрози викидня (больовий синдром, геморагії). Для прогнозування плацентарної дисфункції має значення наявність сильного кореляційного зв'язку між об'ємом хоріону i показниками маткового кровотоку [23, 24, 28, 29, 30].

У медицині застосовують математичні моделі різних модифікацій для прогнозування. Використовують методи, що базуються на теоремі Байєса. Для диференційованого прогнозування двох можливих станів застосовують метод Вальда - послідовний статистичний аналіз та його модифікації, за якого аналізують лише однорідну інформацію. Патометричний алгоритм розпізнавання за Вальдом відрізняється від алгоритму за Байєсом застосуванням «зупинки за Вальдом», яка полягає у тому, що послідовне перемноження співвідношень вірогідностей симптомів при станах A1(y жінки високий ризик не виношування вагітності (НВ)) і А2 (низький ризик НВ) припиняється після досягнення одного із двох діагностичних порогів, визначених, виходячи із заздалегідь обраного припустимого рівня діагностичних помилок $(\leq 5 \%)$.

Враховуючи, що у клінічній практиці здебільшого доводиться приймати рішення, виходячи із неоднорідної інформації, більш обгрунтованим $є$ використання модифікації класичного послідовного аналізу (метод неоднорідного послідовного аналізу). Завдання алгоритму прогнозування - для конкретної жінки на підставі даних аналізу факторів ризику iз певною заздалегідь встановленою вірогідністю вибирати одне $з$ двох прогностичних рішень: перше у жінки високий ризик НВ (стан А1), друге - низький ризик НВ (стан А2). Співвідношення вірогідностей, достатнє для прийняття гіпотез (стан А1 і стан A2), називають «порогами». Збір діагностичної інформації і перемноження відношень вірогідностей виявлених симптомів продовжують до досягнення одного із порогів. Величини порогів визначають за формулою, яка враховує ймовірність помилок, пов'язаних із хибнопозитивним і хибнонегативним результатом аналізу. У медичних дослідженнях ймовірність помилки сягає 0,05 [25].

Говсєєвим Д.О. розроблено шкалу для оцінки розвитку гестаційних ускладнень (табл. 1). При індивідуальній проспективній оцінці кількість балів 9 і вище вказує на високий ризик розвитку ускладнень

Шкала оцінки розвитку гестаційних ускладнень (Говсєєв Д.О., 2019)

Таблиця 1

\begin{tabular}{|l|c|c|c|c|c|c|c|}
\hline \multicolumn{1}{|c|}{ Ознака } & ВР1 & Шанс & ВШ2 & ВП & Бал \\
\hline Паління & \multicolumn{1}{|c|}{ Соціальні фактори } \\
\hline Дефіцит маси тіла & 1,44 & 15,7 & 8,44 & 7,44 & 7 \\
\hline Незареєстрований шлюб & 1,09 & 2,75 & 1,34 & 1,3 & 1 \\
\hline \multicolumn{2}{|c|}{ Акушерсько-гінекологічний анамнез } & 1,06 & 2,45 & 1,21 & 1,15 & 1 \\
\hline Рубець на матці & 1,12 & 3,0 & 1,46 & 1,44 & 1 \\
\hline Безпліддя & 1,09 & 2,71 & 1,31 & 1,29 & 1 \\
\hline
\end{tabular}


Продовження таблиці 1

\begin{tabular}{|c|c|c|c|c|c|}
\hline Мимовільні аборти & 1,32 & 6,0 & 3,21 & 2,5 & 3 \\
\hline $\begin{array}{l}\text { Три і більше мимовільних і/ або штучних } \\
\text { абортів в анамнезі }\end{array}$ & 1,26 & 4,88 & 2,46 & 2,39 & 2 \\
\hline Передчасні пологи & 1,44 & 1,0 & 6,21 & 5,38 & 5 \\
\hline Прееклампсія & 1,32 & 4,88 & 2,87 & 2,3 & 2 \\
\hline \multicolumn{6}{|c|}{ Соматичні захворювання } \\
\hline Гіпертонічна хвороба & 1,36 & 9,5 & 4,79 & 4,44 & 4 \\
\hline Ожиріння & 1,23 & 4,26 & 2,2 & 2,02 & 2 \\
\hline Захворювання нирок & 1,06 & 2,45 & 1,23 & 1,14 & 1 \\
\hline Анемія у ранні терміни вагітності & 1,3 & 2,33 & 1,15 & 1,09 & 1 \\
\hline \multicolumn{6}{|c|}{ Результати скринінг-обстеження } \\
\hline $\begin{array}{l}\text { Сироваткова концентрація РАРР-А 2,2 мкг/мл у } \\
\text { 10-11 тиж }\end{array}$ & 1,21 & 3,29 & 1,91 & 1,36 & 1 \\
\hline Носійство Clamydia trachomatis & 1,22 & 4,4 & 2,18 & 1,97 & 2 \\
\hline Носійство Toxoplasma gondii & 1,24 & 4,58 & 2,35 & 2,11 & 2 \\
\hline \multicolumn{6}{|c|}{ Додаткові лабораторні тести у ранні терміни вагітності } \\
\hline $\begin{array}{l}\text { Сироваткова концентрація стабільних } \\
\text { метаболітів NO } 8 / 2 \text { мкM/л }\end{array}$ & 1,93 & 8,0 & 1,69 & 6,2 & 6 \\
\hline $\begin{array}{l}\text { Сироваткова концентрація С-реактивного білка } \\
8,0 \text { мг/л }\end{array}$ & 1,61 & 8,5 & 6,8 & 4,67 & 5 \\
\hline $\begin{array}{l}\text { Сироваткова концентрація С-реактивного білка } \\
2,9 \text { мг/л }\end{array}$ & 1,18 & 2,83 & 1,69 & 1,57 & 2 \\
\hline
\end{tabular}

Примітки: ВР - відносний ризик, ВШ - відношення шансів, ВП-достовірність відмінностей

вагітності [26].

Отже, перинатальні аспекти невиношування вагітності, попри успіхи у вивченні патогенетичних механізмів, продовжують залишатися провідними у сучасному акушерстві. Формування груп ризику, розроблення алгоритмів прогнозування гестаційних ускладнень та своєчасна діагностика невиношування вагітності надасть можливість покращити перинатальні наслідки. Тому пріоритетним завданням, спрямованим на зниження репродуктивних втрат, $є$ профілактика невиношування вагітності шляхом пошуку нових скринінгових маркерів, які виявлятимуть доклінічні форми патології.

\section{Висновки}

Показана необхідність подальшого вивчення цієї проблеми, 3 урахуванням етіопатогенезу, 3 метою розроблення алгоритмів прогнозування гестаційних ускладнень та вчасної діагностики, що дасть змогу покращити перинатальні наслідки. Тому пріоритетним завданням, спрямованим на зниження репродуктивних втрат, $\epsilon$ профілактика невиношування вагітності шляхом пошуку нових скринінгових маркерів, які виявлятимуть доклінічні форми патології.

\section{Список літератури}

1. Батрак НВ, Малышкина АИ, Сотникова НЮ, Крошкина НВ. Факторы риска и иммунологические механизмы угрозы прерывания беременности ранних сроков и привычного невынашивания. Иваново; 2020. 120 с.
2. Трифонова ЕА, Ганьжа ОА, Габидулина ТВ, Девятьярова ЛЛ, Сотникова ЛС, Степанов ВА. Генетические факторы в развитии привычного невынашивания беременности: обзор данных мета-анализов. Акушерство и гинекология. 2017;4:14-20. doi: 10.18565/aig.2017.4.14-20

3. Хириева ПМ, Мартынов СА, Ежова ЛС, Адамян ЛВ. Клинико-морфологические особенности эндометрия при внутриматочных синехиях: оценка экспрессии эстрогеновых и прогестероновых рецепторов. Акушерство и гинекология. 2018;9:48-54. doi: 10.18565/aig.2018.9.48-54

4. Булавенко ОВ, Мунтян ОА. Прогнозування ризику переривання вагітності у жінок із звичним невиношуванням в анамнезі. Biomedical and Biosocial Anthropology. 2017;28:1479.

5. Булатова ЮС, Тетруашвили НК, Высоких МЮ. Провоспалительные факторы митохондриального происхождения в патогенезе привычных выкидышей и ранних преждевременных родов. Акушерство и гинекология. 2017;8:5-9. doi: 10.18565/aig.2018.4.42-48

6. Atia TA. Placental apoptosis in recurrent miscarriage. Kaohsiung J Med Sci. 2017;33(9):449-52. doi: 10.1016/j.kjms.2017.06.012

7. Менжинская ИВ, Ванько ЛВ. Антифосфолипидные антитела как диагностические маркеры акушерского антифосфолипидного синдрома. Акушерство и гинекология. 2019;2:5-12. doi: 10.18565/aig.2019.2.5-12

8. Ding J, Yin T, Yan N, Cheng Y, Yang J. FasL on decidual macrophages mediates trophoblast apoptosis: a potential cause of recurrent miscarriage. Int J Mol Med. 2019;43(6):2376-86. doi: 10.3892/ijmm.2019.4146

9. Булатова ЮС, Тетруашвили НК, Вишнякова ПА, Высоких МЮ, Марей МВ, Бобров МЮ, и др. Митохондриальные белки микровезикул плазмы периферической крови как триггеры асептических воспалительных реакций у женщин с угрожающим и привычным выкидышем и физиологическим Клінічна та експериментальна патологія. 2021. Т.20, № 3 (77) 
течением беременности. Акушерство и гинекология. 2018;4:42-8. doi: 10.18565/aig.2018.4.42-48

10. Karara JR, Tomas SZ, Marušić J, Roje D, Prusac IK. Fas and FasL expression in placentas complicated with intrauterine growth retardation with and without preeclampsia. J Matern Fetal Neonatal Med. 2016;29(7):1154-9. doi: 10.3109/14767058.2015.1038702

11. Камилова МЯ, Рахматуллоева ДМ, Арабова СУ. Изменения плацентарных гормонов и маркеров апоптоза у женщин с угрозой прерывания беременности и отягощенным невынашиванием беременности. Sciences of Europe. 2017;1(14):45-8.

12. Tao H, Liu X, Liu X, Liu W, Wu D, Wang R, et al. LncRNA MEG3 inhibits trophoblast invasion and trophoblast-mediated VSMC loss in uterine spiral artery remodeling. Mol Reprod Dev. 2019;86(6):686-95. doi: 10.1002/mrd.23147

13. Chen MH, Kan HT, Liu CY, Yu WK, Lee SS, Wang JH, et al. Serum decoy receptor 3 is a biomarker for disease severity in nonatopic asthma patients. J Formos Med Assoc. 2017;116(1):4956. doi: 10.1016/j.jfma.2016.01.007

14. Yeh CC, Yang MJ, Lussier EC, Tsai HW, Lo PF, Hsieh SL, et al. Low plasma levels of decoy receptor 3 (DcR3) in the third trimester of pregnancy with preeclampsia. Taiwan J Obstet Gynecol. 2019;58(3):349-53. doi: 10.1016/j.tjog.2019.03.011

15. Лоскутова ТО, Давиденко НВ, Крячкова НВ, Петулько АП. Прогноз звичного невиношування вагітності, асоційованого 3 генетичними формами тромбофілії. Актуальні питання педіатрії, акушерства та гінекології. 2017;1:90-4. doi: 10.11603/24116-4944.2017.1.7336

16. Bao SH, Chigirin N, Hoch V, Ahmed H, Frempong ST, Zhang M, et al. Uterine Radial Artery Resistance Index Predicts Reproductive Outcome in Women with Recurrent Pregnancy Losses and Thrombophilia. BioMed Research International [Internet]. 2019[cited 2021 Jun 29];2019:8787010. Available from: https:// downloads.hindawi.com/journals/bmri/2019/8787010.pdf doi: $10.1155 / 2019 / 8787010$

17. Van Dijk M, Kolte A, Limpens J, Kirk E, Quenby S, van Wely $\mathrm{M}$, et al. Recurrent pregnancy loss: diagnostic workup after two or three pregnancy losses? A systematic review of the literature and meta-analysis. Hum Reprod Update. 2020;26(3):356-67. 10.1093/humupd/dmz048

18. Zhao X, Zhao Y, Ping Y, Chen L, Feng X. Association between gene polymorphism of folate metabolism and recurrent spontaneous abortion in Asia. Medicine (Baltimore) [Internet]. 2020[cited 2021 Jun 30];99(40):e21962. Available from: https:// www.ncbi.nlm.nih.gov/pmc/articles/PMC7535684/pdf/medi99-e21962.pdf doi: 10.1097/md.0000000000021962

19. Лоскутова ТО, Давиденко НВ, Чулков ОС. Прогнозування звичного невиношування вагітності. Sciences of Europe 2021;2(63):25-31. doi: 10.24412/3162-2364-2021-63-2-25-31

20. Утробин МВ, Юрьев СЮ. Возможности прогнозирования привычного выкидыша в предгравидарном периоде Бюллетень медицинской науки. 2020;2:39-42.

21. Кухарчик ЮВ. Биогенные амины в прогнозировании невынашивания беременности в I триместре. В: Лелевич BВ, редактор. Материалы науч.-практ. конф. с междунар. участием, посвящ. 60-летию создания кафедры биологической химии ГрГМУ; 2019 Май 31; Гродно. Гродно; 2019, с. 180-3.

22. Ткаченко АВ. Профілактика перинатальних втрат i акушерських ускладнень при вагітності двійнею [дисертація]. Київ; 2021. 353 с.

23. Рубан ЯА. Плацентарна дисфункція після допоміжних репродуктивних технологій: прогнозування, тактика ведення вагітності і розродження [дисертація]. Київ; 2021. 306 с.

24. Борзенко ІБ. Прогнозування та рання діагностика плацентарної дисфункції (огляд літератури). Український журнал медицини, біології та спорту. 2020;5(2):7-17. doi: $10.26693 / \mathrm{jmbs} 05.02 .007$

25. Герзанич СО, Мулеса ОЮ. Алгоритм прогнозування невиношування вагітності в умовах природного йодного дефіциту. Здоровье женшины. 2018;8:48-51. doi: 10.15574/ HW.2018.134.48

26. Говсеєв ДО. Прогнозування повторних ускладнень гестації у жінок 3 високим перинатальним ризиком. Современная педиатрия. 2019;3:25-9. doi: 10.15574/SP.2019.99.25

27. Литвин НВ. Діагностика та профілактика відшарування хоріона у жінок після застосування допоміжних репродуктивних технологій [дисертація]. Івано-Франківськ; 2017. 211 c

28. Литвин НВ. Оцінка специфічних білків вагітності для прогнозування ранніх репродуктивних втрат у жінок, включених у програму допоміжних репродуктивних технологій. Збірник наукових праць Асоціації акушерівгінекологів України. 2017;1:99-103.

29. Дука ЮМ. Прогнозування ризиків переривання вагітності у вагітних жінок із загрозою невиношування вагітності залежно від маси тіла жінки. Sciences of Europe. 2017;2(19):55-62.

30. Гичка НМ. Особливості вагітності, пологів, стану плода та новонародженого у жінок з невиношуванням в анамнез (Ретроспективний аналіз). Здоровье женщины. 2019;3:44-8. doi: 10.15574/HW.2019.139.44

\section{References}

1. Batrak NV, Malyshkina AI, Sotnikova NYu, Kroshkina NV. Faktory riska i immunologicheskie mekhanizmy ugrozy preryvaniya beremennosti rannikh srokov i privychnogo nevynashivaniya [Risk factors and immunological mechanisms of the threat of early termination of pregnancy and recurrent miscarriage]. Ivanovo; 2020. 120 p. (in Russian)

2. Trifonova EA, Ganzha OA, Gabidulina TV, Devyatyarova LL, Sotnikova LS, Stepanov VA. Geneticheskie faktory v razvitii privychnogo nevynashivaniya beremennosti: obzor dannykh meta-analizov [Genetic factors in the development of recurrent miscarriage: an overview of the data of meta-analyses]. Akusherstvo i Ginekologiya. 2017;4:14-20. doi: 10.18565/ aig.2017.4.14-20 (in Russian)

3. Khirieva PM, Martynov SA, Ezhova LS, Adamyan LV. Klinikomorfologicheskie osobennosti endometriya pri vnutrimatochnykh sinekhiyakh: otsenka ekspressii estrogenovykh i progesteronovykh retseptorov [Clinical and morphological characteristics of the endometrium in intrauterine synechiae: evaluation of the expression of estrogen and progesterone receptors]. Akusherstvo i Ginekologiya. 2018;9:48-54. doi: 10.18565/aig.2018.9.48-54 (in Russian)

4. Bulavenko OV, Muntian OA. Prohnozuvannia ryzyku pereryvannia vahitnosti u zhinok iz zvychnym nevynoshuvanniam $\mathrm{v}$ anamnezi [Prediction of the risk of abortion in women with recurrent miscarriage]. Biomedical and Biosocial Anthropology. 2017;28:147-9. (in Ukrainian)

5. Bulatova YS, Tetruashvili NK, Vysokikh MY. Provospalitel'nye faktory mitokhondrial'nogo proiskhozhdeniya $\mathrm{V}$ patogeneze privychnykh vykidyshey i rannikh prezhdevremennykh rodov [Pro-inflammatory factors of mitochondrial origin in the pathogenesis of recurrent miscarriages and early preterm birth]. Akusherstvo i Ginekologiya. doi: 10.18565/aig.2018.4.42-48 (in Russian)

6. Atia TA. Placental apoptosis in recurrent miscarriage. Kaohsiung J Med Sci. 2017;33(9):449-52. doi: 10.1016/j.kjms.2017.06.012

7. Menzhinskaya IV, Vanko LV. Antifosfolipidnye antitela kak 
diagnosticheskie markery akusherskogo antifosfolipidnogo sindroma [Antiphospholipid antibodies as diagnostic markers for obstetric antiphospholipid syndrome]. Akusherstvo i Ginekologiya. 2019;2:5-12. doi: 10.18565/aig.2019.2.5-12 (in Russian)

8. Ding J, Yin T, Yan N, Cheng Y, Yang J. FasL on decidual macrophages mediates trophoblast apoptosis: a potential cause of recurrent miscarriage. Int J Mol Med. 2019;43(6):2376-86. doi: 10.3892/ijmm.2019.4146

9. Bulatova YS, Tetruashvili NK, Vishnyakova PA, Vysokikh MY, Marei MV, Bobrov MYu, et al. Mitokhondrial'nye belki mikrovezikul plazmy perifericheskoy krovi kak triggery asepticheskikh vospalitel'nykh reaktsiy u zhenshchin s ugrozhayushchim i privychnym vykidyshem i fiziologicheskim techeniem beremennosti [Mitochondrial proteins of peripheral plasma microvesicles as triggers of aseptic inflammatory responses in women with threatened, recurrent abortion and physiological pregnancy]. Akusherstvo i Ginekologiya. doi: 10.18565/aig.2018.4.42-48 (in Russian)

10. Karara JR, Tomas SZ, Marušić J, Roje D, Prusac IK. Fas and FasL expression in placentas complicated with intrauterine growth retardation with and without preeclampsia. J Matern Fetal Neonatal Med. 2016;29(7):1154-9. doi: 10.3109/14767058.2015.1038702

11. Kamilova MY, Rakhmatulloeva DM, Arabova SU. Izmeneniya platsentarnykh gormonov i markerov apoptoza u zhenshchin s ugrozoy preryvaniya beremennosti i otyagoshchennym nevynashivaniem beremennosti [Changes of placental hormones and apoptosis markers in women with the threat of abortion and aggravated miscarriages]. Sciences of Europe. 2017;1(14):45-8. (in Russian)

12. Tao H, Liu X, Liu X, Liu W, Wu D, Wang R, et al. LncRNA MEG3 inhibits trophoblast invasion and trophoblast-mediated VSMC loss in uterine spiral artery remodeling. Mol Reprod Dev. 2019;86(6):686-95. doi: 10.1002/mrd.23147

13. Chen MH, Kan HT, Liu CY, Yu WK, Lee SS, Wang JH, et al. Serum decoy receptor 3 is a biomarker for disease severity in nonatopic asthma patients. J Formos Med Assoc. 2017;116(1):4956. doi: 10.1016/j.jfma.2016.01.007

14. Yeh CC, Yang MJ, Lussier EC, Tsai HW, Lo PF, Hsieh SL, et al. Low plasma levels of decoy receptor 3 (DcR3) in the third trimester of pregnancy with preeclampsia. Taiwan J Obstet Gynecol. 2019;58(3):349-53. doi: 10.1016/j.tjog.2019.03.011

15. Loskutova TO, Davydenko NV, Kriachkova NV, Petul'ko AP. Prohnoz zvychnoho nevynoshuvannia vahitnosti, asotsiiovanoho $z$ henetychnymy formamy trombofilii [Prognosis of recurrent pregnancy loss associated with heredity thrombophilia]. Aktual'ni pytannia pediatrii, akusherstva ta hinekolohii. 2017;1:90-4. doi: 10.11603/24116-4944.2017.1.7336 (in Ukrainian)

16. Bao SH, Chigirin N, Hoch V, Ahmed H, Frempong ST, Zhang M, et al. Uterine Radial Artery Resistance Index Predicts Reproductive Outcome in Women with Recurrent Pregnancy Losses and Thrombophilia. BioMed Research International [Internet]. 2019[cited 2021 Jun 29];2019:8787010. Available from: https:// downloads.hindawi.com/journals/bmri/2019/8787010.pdf doi: $10.1155 / 2019 / 8787010$

17. Van Dijk M, Kolte A, Limpens J, Kirk E, Quenby S, van Wely $\mathrm{M}$, et al. Recurrent pregnancy loss: diagnostic workup after two or three pregnancy losses? A systematic review of the literature and meta-analysis. Hum Reprod Update. 2020;26(3):356-67. 10.1093/humupd/dmz048

18. Zhao X, Zhao Y, Ping Y, Chen L, Feng X. Association between gene polymorphism of folate metabolism and recurrent spontaneous abortion in Asia. Medicine (Baltimore) [Internet]. 2020[cited 2021 Jun 30];99(40):e21962. Available from: https:// www.ncbi.nlm.nih.gov/pmc/articles/PMC7535684/pdf/medi99-e21962.pdf doi: 10.1097/md.0000000000021962
19. Loskutova T, Davydenko N, Chulkov O. Prohnozuvannia zvychnoho nevynoshuvannia vahitnosti [Prediction of recurrent miscarriage]. Sciences of Europe. 2021;2(63):25-31. doi: 10.24412/3162-2364-2021-63-2-25-31 (in Ukrainian)

20. Utrobin MV, Yur'ev SYu. Vozmozhnosti prognozirovaniya privychnogo vykidysha $\mathrm{v}$ predgravidarnom periode [Possibilities for predicting habitual miscarriage in the pregravid period]. Byulleten' meditsinskoy nauki. 2020;2:39-42. (in Russian)

21. Kukharchik YuV. Biogennye aminy $\mathrm{v}$ prognozirovanii nevynashivaniya beremennosti $\mathrm{v}$ I trimestre [Biogenic amines in predicting miscarriage in the first trimester]. V: Lelevich VV, redaktor. Materialy nauch.-prakt. konf. s mezhdunar. uchastiem, posvyashch. 60-letiyu sozdaniya kafedry biologicheskoy khimii GrGMU; 2019 May 31; Grodno. Grodno; 2019, p. 180-3. (in Russian)

22. Tkachenko AV. Profilaktyka perynatal'nykh vtrat i akushers'kykh uskladnen' pry vahitnosti dviineyu [Prevention of perinatal losses and obstetric complications during twin pregnancy] [dysertatsiia]. Kiev; 2021. 353 p. (in Ukrainian)

23. Ruban YaA. Platsentarna dysfunktsiia pislia dopomizhnykh reproduktyvnykh tekhnolohii: prohnozuvannia, taktyka vedennia vahitnosti i rozrodzhennia [Placenta disfunction after auxiliary genesial technologies: prognostication, tactic of conduct of pregnancy and delivery] [dysertatsiia]. Kiev; 2021. 306 p. (in Ukrainian)

24. Borzenko IB. Prohnozuvannia ta rannia diahnostyka platsentarnoi dysfunktsii (ohliad literatury) [Prediction and Early Diagnosis of Placental Dysfunction (Literature Review)]. Ukrains'kyi Zhurnal Medytsyny, Biolohii ta Sportu. 2020;5(2):7-17. doi: 10.26693/ jmbs05.02.007 (in Ukrainian)

25. Gerzanych SO, Mulesa OYu. Alhorytm prohnozuvannia nevynoshuvannia vahitnosti $\mathrm{v}$ umovakh pryrodnoho yodnoho defitsytu [The logistic model for prediction of miscarriage in conditions of natural iodine deficiency]. Health of Woman. 2018;8:48-51. doi: 10.15574/HW.2018.134.48 (in Ukrainian)

26. Govseev DA. Prohnozuvannia povtornykh uskladnen' hestatsii u zhinok z vysokym perynatal'nym ryzykom [Forecasting of repeated complications at women with high perinatal risk]. Sovremennaya pediatriya. 2019;3:25-9. doi: 10.15574/ SP.2019.99.25 (in Ukrainian)

27. Lytvyn NV. Diahnostyka ta profilaktyka vidsharuvannia khoriona u zhinok pislia zastosuvannia dopomizhnykh reproduktyvnykh tekhnolohii [Diagnosis and prophylaxis of chorionic detachment in women after the use of assisted reproductive technologies] [dysertatsiia]. Ivano-Frankivs'k; 2017. 211 p. (in Ukrainian)

28. Lytvyn NV. Otsinka spetsyfichnykh bilkiv vahitnosti dlia prohnozuvannia rannikh reproduktyvnykh vtrat u zhinok, vkliuchenykh $\mathrm{u}$ prohramu dopomizhnykh reproduktyvnykh tekhnolohii [Prognosis and prevention of trophoblast invasia processes and early reproductive losses in women with treated infertility included into the program of assisted reproductive technologies]. Scientific digest of Association of obstetricians and gynaecologists of Ukraine. 2017;1:99-103. (in Ukrainian)

29. Duka YM. Prohnozuvannia ryzykiv pereryvannia vahitnosti u vahitnykh zhinok iz zahrozoiu nevynoshuvannia vahitnosti zalezhno vid masy tila zhinky [Prediction of pregnancy of pregnancy of pregnancy in pregnant women with thereat of injection pregnancy depending on the weight of the body of the woman]. Sciences of Europe. 2017;2(19):55-62. (in Ukrainian)

30. Hychka NM. Osoblyvosti vahitnosti, polohiv, stanu ploda ta novonarodzhenoho u zhinok $\mathrm{z}$ nevynoshuvanniam $\mathrm{v}$ anamnezi (Retrospektyvnyi analiz) [Features of pregnancy, delivery, the condition of the fetus and newborn in women with miscarriage in history (Retrospective analysis)]. Health of Woman. 2019;3:44-8. doi: 10.15574/HW.2019.139.44 (in Ukrainian) 
Відомості про автора:

Соловей В.М. - асистент кафедри акушерства, гінекології та перинатології, Буковинський державний медичний університет, м. Чернівці, Україна.

\section{Сведения об авторе:}

Соловей В.М. - ассистент кафедры акушерства, гинекологии и перинатологии, Буковинский государственный медицинский университет, г. Черновцы, Украина.

Information about the autor:

Solovei V.M. - Assistant of the Department of Obstetrics, Gynecology and Perinatology, Bukovinian State Medical University, Chernivtsi, Ukraine.

Стаття надійшла до редакиії 27.07.2021 p.

Рецензент - проф. Юзько О.М.

(C) В.М. Соловей, 2021

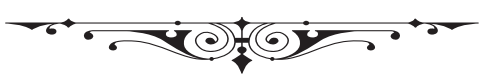

